\title{
Plateau subduction, intraslab seismicity, and the Denali (Alaska) volcanic gap
}

\author{
by \\ Yuling (Lindsay) Chuang \\ B.A., National Taiwan Normal University, 2009 \\ M.Sc., National Taiwan Normal University, 2012 \\ A THESIS SUBMITTED IN PARTIAL FULFILLMENT OF \\ THE REQUIREMENTS FOR THE DEGREE OF \\ MASTER OF SCIENCE \\ in \\ THE FACULTY OF GRADUATE AND POSTDOCTORAL STUDIES \\ (Geophysics) \\ THE UNIVERSITY OF BRITISH COLUMBIA \\ (Vancouver) \\ January 2018 \\ (C) Yuling (Lindsay) Chuang, 2018
}




\section{Abstract}

Tectonic tremors in Alaska (USA) are associated with subduction of the Yakutat plateau, but their origins are unclear due to lack of depth constraints. We have processed tremor recordings to extract low-frequency earthquakes (LFEs), and generated a set of six LFE waveform templates via iterative network matched filtering and stacking. The timing of impulsive $\mathrm{P}$ (compressional) wave and $\mathrm{S}$ (shear) wave arrivals on template waveforms places LFEs at 40-58 $\mathrm{km}$ depth, near the upper envelope of intraslab seismicity and immediately updip of increased levels of intraslab seismicity. S waves at near-epicentral distances display polarities consistent with shear slip on the plate boundary. We compare characteristics of LFEs, seismicity, and tectonic structures in central Alaska with those in warm subduction zones, and propose a new model for the region's unusual intraslab seismicity and the enigmatic Denali volcanic gap (i.e., an area of no volcanism where expected). We argue that fluids in the Yakutat plate are confined to its upper crust, and that shallow subduction leads to hydromechanical conditions at the slab interface in central Alaska akin to those in warm subduction zones where similar LFEs and tremor occur. These conditions lead to fluid expulsion at shallow depths, explaining strike-parallel alignment of tremor occurrence with the Denali volcanic gap. Moreover, the lack of double seismic zone and restriction of deep intraslab seismicity to a persistent low-velocity zone are simple consequences of anhydrous conditions prevailing in the lower crust and upper mantle of the Yakutat plate. 


\section{Lay Summary}

We apply a match-filtered technique to 13 3-component, broadband stations from central Alaska and recover 6 low-frequency earthquake (LFE) templates. These LFEs are located at depth ranges from 40 to $58 \mathrm{~km}$, near the upper envelope of intraslab seismicity and immediately updip of increased levels of intraslab seismicity. We further compare the characteristics of LFEs, seismicity, and tectonic structures in central Alaska with those in warm subduction zones, and propose a new model for the region's unusual intraslab seismicity and the enigmatic Denali volcanic gap. We argue that fluids in the Yakutat plate are confined to its upper crust, and that shallow subduction leads to hydromechanical conditions at the slab interface in central Alaska akin to those in warm subduction zones where similar LFEs and tremor occur. These conditions lead to fluid expulsion at shallow depths, explaining strike-parallel alignment of tremor occurrence with the Denali volcanic gap. 


\section{Preface}

The data presented in this thesis were analyzed by Yuling Chuang, under the supervision of Dr. Michael Bostock. A version of this thesis has been published. Lindsay Chuang, Michael Bostock, Aaron Wech, and Alexandre Plourde. (2017) Plateau subduction, intraslab seismicity, and the Denali (Alaska) volcanic gap. Geology, G38867.1, first published on May 8, 2017, doi:10.1130/G38867.1. 


\section{Table of Contents}

Abstract..............................................................................................................ii

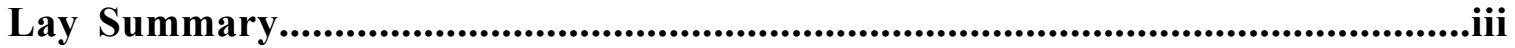

Preface..........................................................................................................iv

Table of Contents...........................................................................................v

List of Tables.........................................................................................................vi

List of Figures.............................................................................................vii

Acknowledgements..........................................................................................................viii

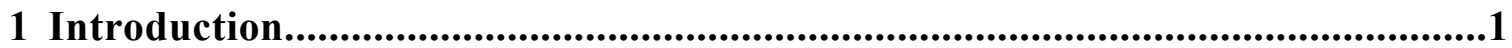

1.1 Models of the origins of volcanic gaps...................................................

1.2 The Yakutat terrane and associated Denali Volcanic Gap..........................

2 Method and Results..........................................................5

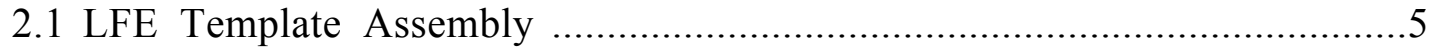

2.2 LFE Template Hypocentral Location..................................... 10

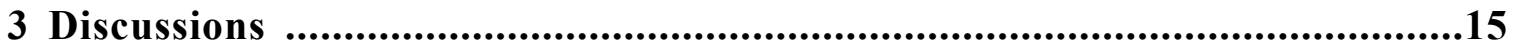

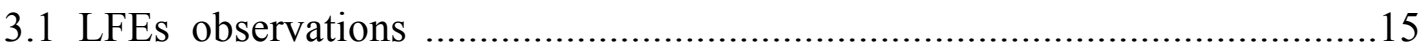

3.2 LFEs and LVZs in Warm Subduction Zones ....................................16

3.3 Fluid Distribution and Seismogenesis ............................. 19

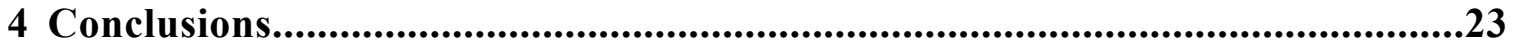

References........................................................................................24 


\section{List of Tables}

Table 2.1 Locations of stations employed in this study.............................................11

Table 2.2 P wave Velocity model of Southern Alaska.................................................12

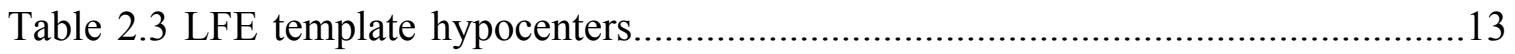




\section{List of Figures}

Figure 2.1 Tectonic setting of south-central Alaska, USA........................................

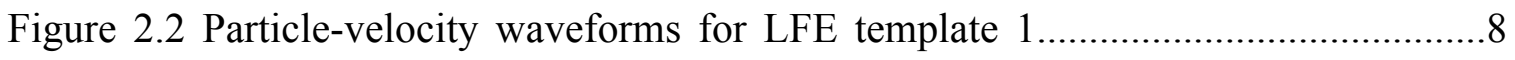

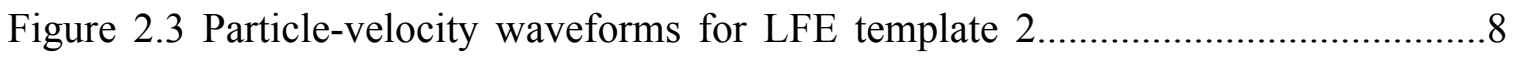

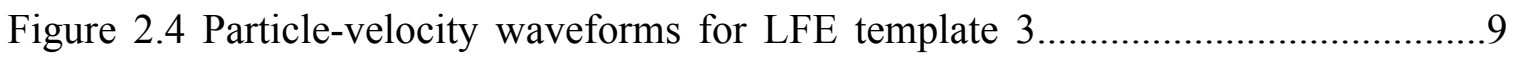

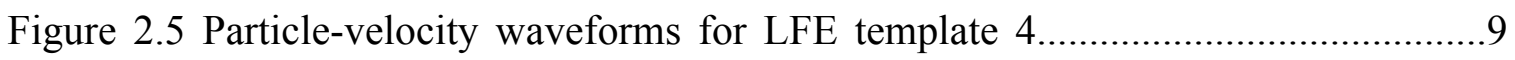

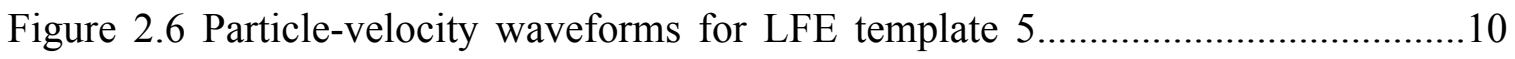

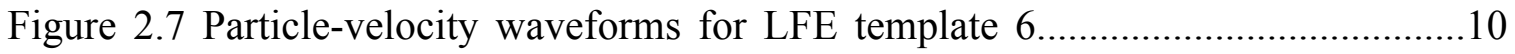

Figure 2.8 Particle velocity waveforms of S-waves on horizontal components at stations

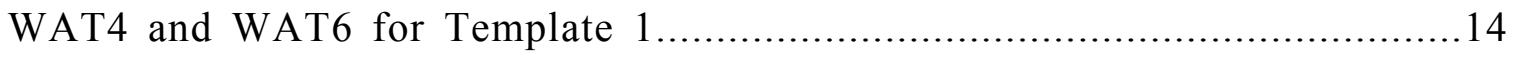

Figure 3.1 Depth distribution of intraslab seismicity and low-frequency earthquakes

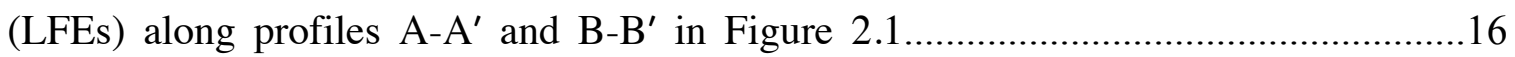

Figure 3.2 Yakutat subduction model.................................................................18 


\section{Acknowledgments}

I offer my enduring gratitude to the faculty, staff and my fellow students at the UBC, who have inspired me to continue my work in this field. I owe particular thanks to my supervisor Dr. Michael Bostock, who has always being patient and supportive. He enlarges my vision of science and providing coherent answers to my questions. I would like to thank my colleagues Alex Plourde, Genevive Savard, Timothy Hayward and Xuejun Han for all the comments and helps they have offered. I thank my friends Chin-Wu Chen, Jessie Chao, Maggie Campbell, Stephanie Plourde, Ting-Chun Kuo, Kate Chen and Keelin Scully, who help me to overcome the obstacles in my abroad study life. Special thanks to my families, whose have supported me throughout my years of education. 


\section{Introduction}

Plate tectonics theory predicts that linear volcanic chains lie parallel to subduction margins. However, major spatial gaps in volcanic chains are evident in various subduction zones. These volcanic gaps represent segments where volcanic activity is absent at the surface even when the necessary conditions (i.e. volatiles/melt at source area, source of heat and proper state of stress in the overlying lithosphere) for volcanic activity may appear favorable (McGeary et. al., 1985). Most volcanic gaps coincide with the collision or subduction of a large aseismic oceanic plateau or ridge. Although it is still unclear how the collision or subduction of an oceanic plateau can perturb the subduction system and inhibit the production of arc volcanism, some models have been proposed.

\subsection{Models of the Origins of Volcanic Gaps}

There is no simple model that can explain how volcanic gaps have formed due to the complex and diverse nature of collision/subduction systems. The characteristics that plateaus inherit (i.e. relative buoyancy, crustal thickness, age and size) and the conditions of convergence (i.e. convergence rate, age of the plate, dip, depth and length of the slab, coupling of at the interface) may all contribute to formation of volcanic gaps. McGeary et. al., 1985 divided volcanic gaps into four different groups and corresponding models based on combinations of characteristics. Those four categories of volcanic gaps are:

(1) Collision/plate boundary reorganization, which happens when a feature embedded within the oceanic crust is buoyant, completely resists subduction and collides with the arc, causing local plate boundaries to reorganize. In this case the melt and water 
supply from slab will be cut off and frictional heating along the plate interface will be reduced. Volcanic gaps are thereby formed. The Cocos Ridge in the Galapagos area and Philippine Sea plate-Eurasian plate in Taiwan are the examples of this type of collision.

(2) Plateau subduction with shallow dip occurs when the oceanic plateau subducts but the dip of the subducting slab becomes very shallow $\left(<15^{\circ}\right)$. When the dip is shallow, the asthenospheric wedge will no longer produce source material or heat for volcanism. This mechanism is evident in subduction at the Nankai Trough and southern Chile.

(3) Plateau subduction with steep dip occurs when oceanic plateaus subduct at steep angles. In this case, the oceanic plateau may change the state of stress of the arc or perturb the source of magma, volatiles or heat at depth and further inhibit volcanism. McGeary et. al., 1985 attribute the main cause of volcanism cessation to perturbation in the supply of volcanic materials. There are three possible ways that the oceanic plateau can perturb the system: (1) the top of the plateau where hydrous minerals and sediments are located is sheared off during subduction; (2) the plateau lacks hydrous minerals; (3) sufficient hydrous minerals exist in the subducted plateau, but dehydration reactions occur too shallow in depth for melting in the mantle wedge to occur. Any of them can cause volcanic gaps by cancelling the fluid budget where the magmas are supposed to be formed. The subduction of the Philippine Sea plate beneath the Eurasian plate in Ryukyu is an example of this category.

(4) There is one category where the volcanic gaps present but no oceanic plateau is subducted. This kind of volcanic gap is hard to explain, but could be a result of the low 
rate and oblique angle of convergence (McGeary et. al., 1985). Such gaps are evident the in Kermadec chain.

\subsection{The Yakutat Terrane and Associated Denali Volcanic Gap}

Along the eastern margin of Alaska, convergence of the oceanic plateau-origin Yakutat terrane and Pacific plate with North America at $\sim 50 \mathrm{~mm} / \mathrm{a}$ to the north-northwest has produced several prominent tectonic features including a flat-slab/shallow subduction regime to the east, a collisional regime to the west, and a paucity of volcanism for $\sim 400$ $\mathrm{km}$ along strike known as the Denali volcanic gap (DVG). Rondenay et al. (2010) argue that advancing, shallow subduction of the Yakutat terrane cools the mantle wedge, creating a melt trap near the base of the overriding North American plate and absent volcanism along the DVG. The model relies on sufficient melts happening at the source area. Offshore tomographic studies reveal a Yakutat crust $24-27 \mathrm{~km}$ in thickness and a velocity structure consistent with an oceanic plateau origin (Christeson et al., 2010).

Receiver function studies along the Multidisciplinary Observations of Onshore Subduction (MOOS) and Broadband Experiment Across the Alaska Range (BEAAR) transects in south-central Alaska identify a 3-5-km-thick low-velocity zone (LVZ) with shallow dip $\left(<5^{\circ}\right)$ at $20-25 \mathrm{~km}$ depth near the coast, transitioning into a $15-20-\mathrm{km}$ thick LVZ with $\sim 20^{\circ}$ dip down to $130 \mathrm{~km}$ depth (Kim et al., 2014). The LVZ is thicker than those observed in other subduction zones, envelops intraslab seismicity in a single seismic zone, and is inferred to represent the subducted Yakutat terrane (Abers et al., 2013). Rondenay et al. (2010) argued that advancing shallow subduction of the Yakutat 
terrane cools the mantle wedge, creating a melt trap near the base of the overriding North American plate and resulting in the absence of volcanism along the DVG. However, in this study we propose an alternative model for the origin of DVG by using low frequency earthquakes as an indication of early dehydration. In our model, fluids are expelled at depths too shallow to allow generation of significant partial melts and arc volcanism. 


\section{Method and Results}

Slow-slip phenomena including tectonic tremors are documented in this region (e.g., Peterson and Christensen, 2009). Applying an automatic detection method, Wech, 2016 defined the limits of a broad tremor zone that correlates with inferred subduction of the Yakutat terrane and the width of the DVG downdip (Fig. 2.1). The dip extent, frequency content, and migration of Alaska tremors are similar to those in warm subduction zones where vigorous tremors more typically occur (Ide, 2012). Wech attributes Alaska tremors to a low effective stress and weak fault environment created by a sediment-rich uppermost Yakutat plate. However, poor depth constraints afforded by tremor location methods make this hypothesis difficult to corroborate. To address this shortcoming, we exploit low-frequency earthquakes (LFEs) that constitute tremor (Shelly et al., 2007). By stacking of thousands of repeating LFEs, distinct $\mathrm{P}$ (compressional) and $\mathrm{S}$ (shear) wave arrivals emerge on LFE template waveforms, enabling precise locations to be determined. We examine locations of LFEs, regular seismicity, and LVZ structure, and compare their signatures to those in warm subduction zones to gain new insights into the relation between fluids, intraplate seismicity, and volcanism in Alaska.

\subsection{LFE Template Assembly}

LFE templates were prepared by selecting 24-hour-long, tremor records from 13 3-component station broadband stations from central Alaska (see Table 1) for dates that were identified by Wech (2015) to exhibit strong tremor activity. These records were instrument corrected to particle velocity, resampled to $40 \mathrm{sps}$ and filtered between $1-8 \mathrm{~Hz}$, 
the dominant tremor frequency band. Horizontal component records organized in a spatially consistent manner were visually examined for signs of discrete LFE arrivals displaying consistent move-out across stations. Waveforms from candidate time windows and subsets of stations where arrivals could be discerned were selected as initial templates within a network matched filter to identify similar repeating waveforms at different times. Detections were registered if the summed network correlation coefficient exceeded 8 times the median absolute deviation, a threshold that has been shown to be a robust criterion for LFE detection (Shelly et al., 2007). If a significant number of detections was registered, a new template was formed by stacking all waveforms corresponding to a given channel (including stations not included within the initial station subset) at the detection times. Those stations exhibiting coherent arrivals were redeployed within the matched filter and the detection stacking process was repeated until significant new detections were no longer found. The final 6 templates at those stations (RND, WAT2-7) typically exhibiting the highest signal-to-noise ratios, are shown in Figures 2.2-2.7. 


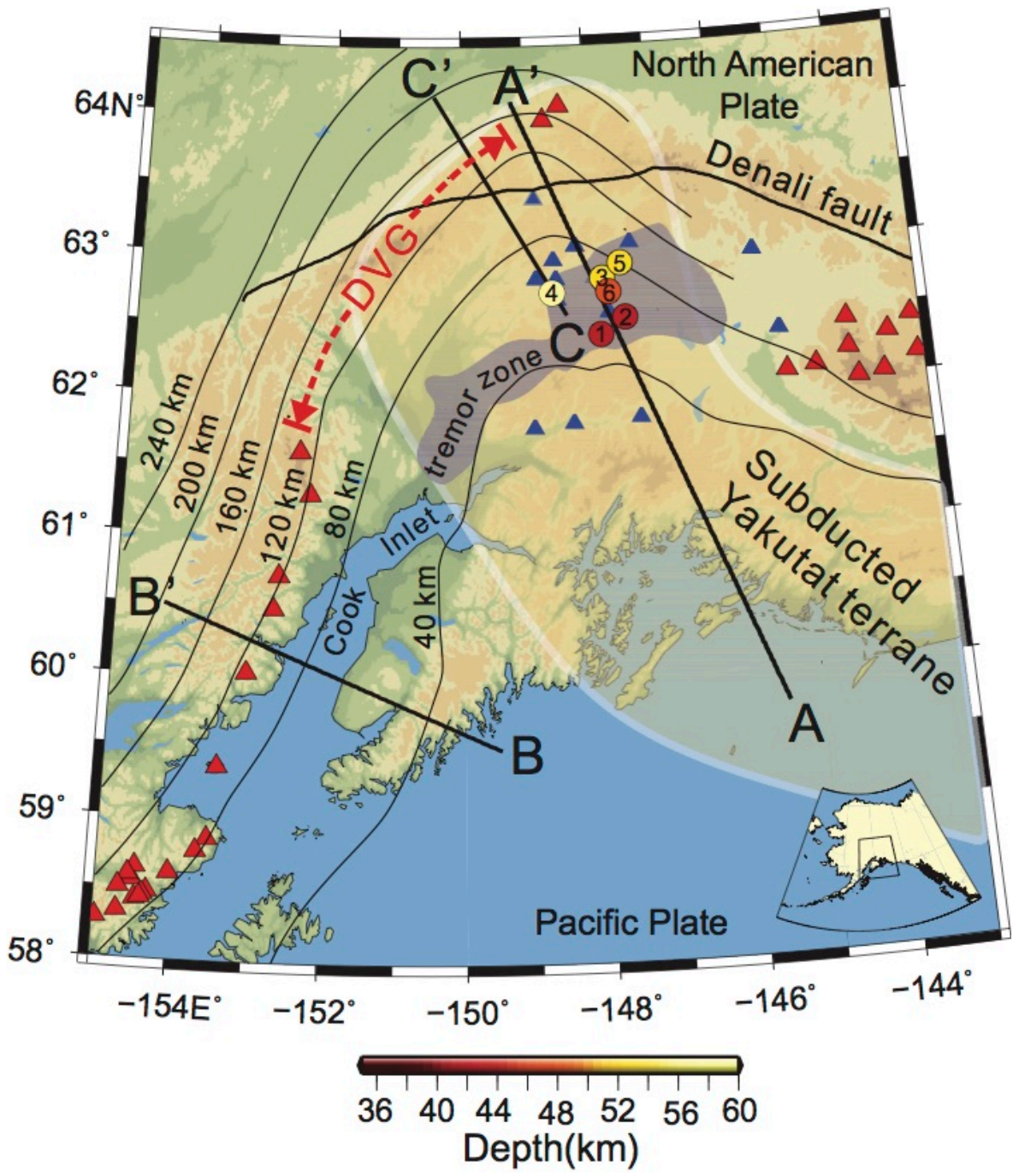

Figure 2.1. Tectonic setting of south-central Alaska, USA. DVG-Denali volcanic gap. Red triangles indicate active volcanoes. Tremor zone is shown in purple. Subducted Yakutat terrane is highlighted in yellow. Plate interface depth contours from E115 (Jadamec and Billen, 2010) are shown. Blue triangles mark seismic stations used in this study. Red and yellow circles indicate locations of the low-frequency earthquakes identified in this study 

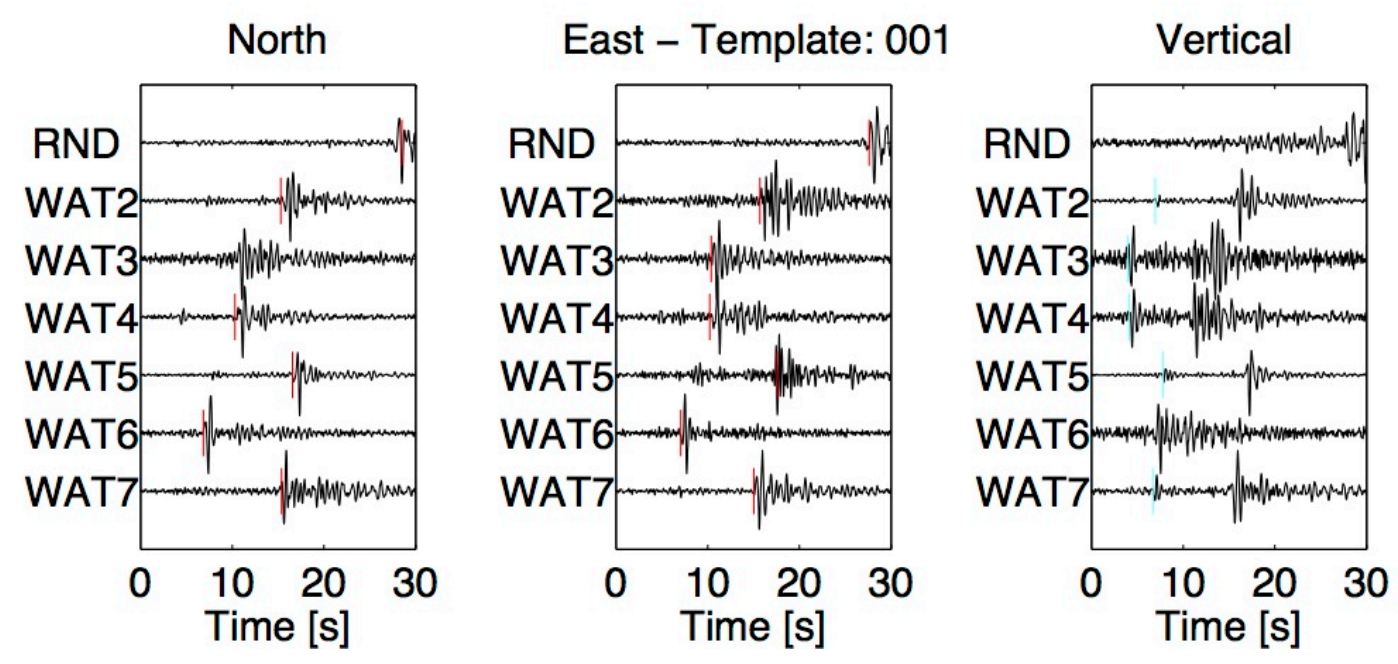

Figure 2.2. Particle-velocity waveforms for LFE template 1. a) North, east, and vertical components are shown in the panels from left to right. Note all traces have been normalized to maximum absolute amplitude. Model-predicted arrival times for S-waves (red) and P-waves (blue) are shown for those waveforms for which arrival times were picked.
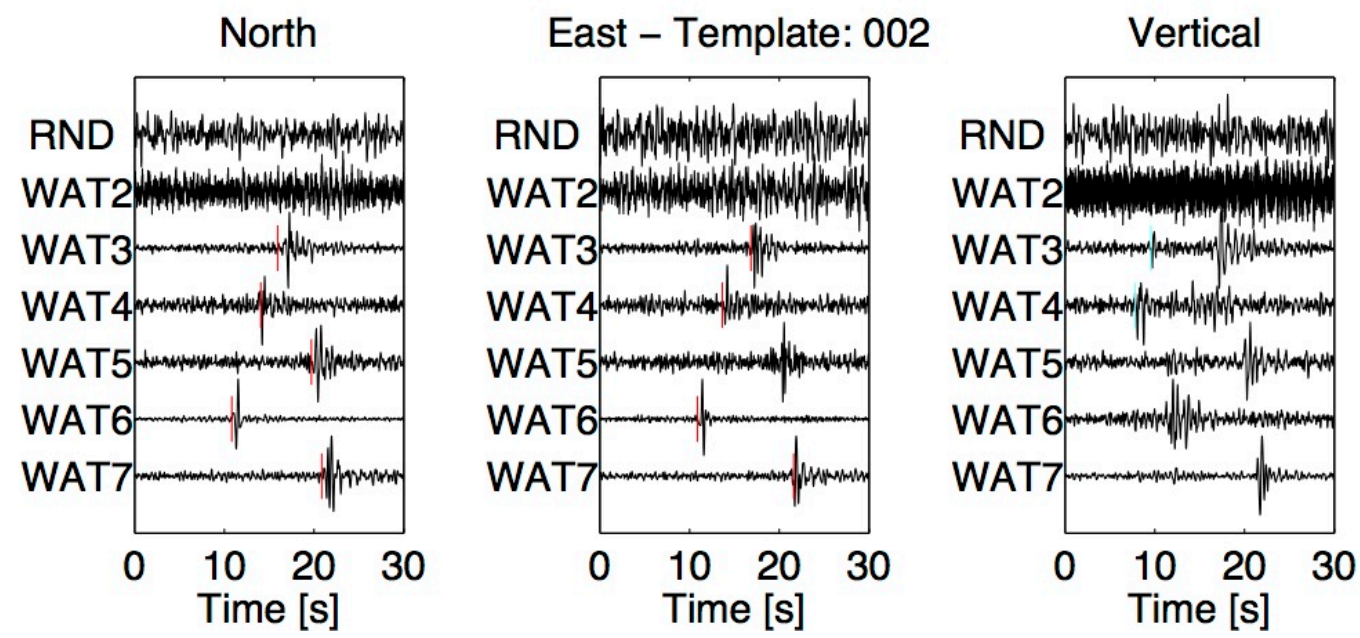

Figure 2.3. Particle-velocity waveforms for LFE template 2. See Figure 2.2 for details. 


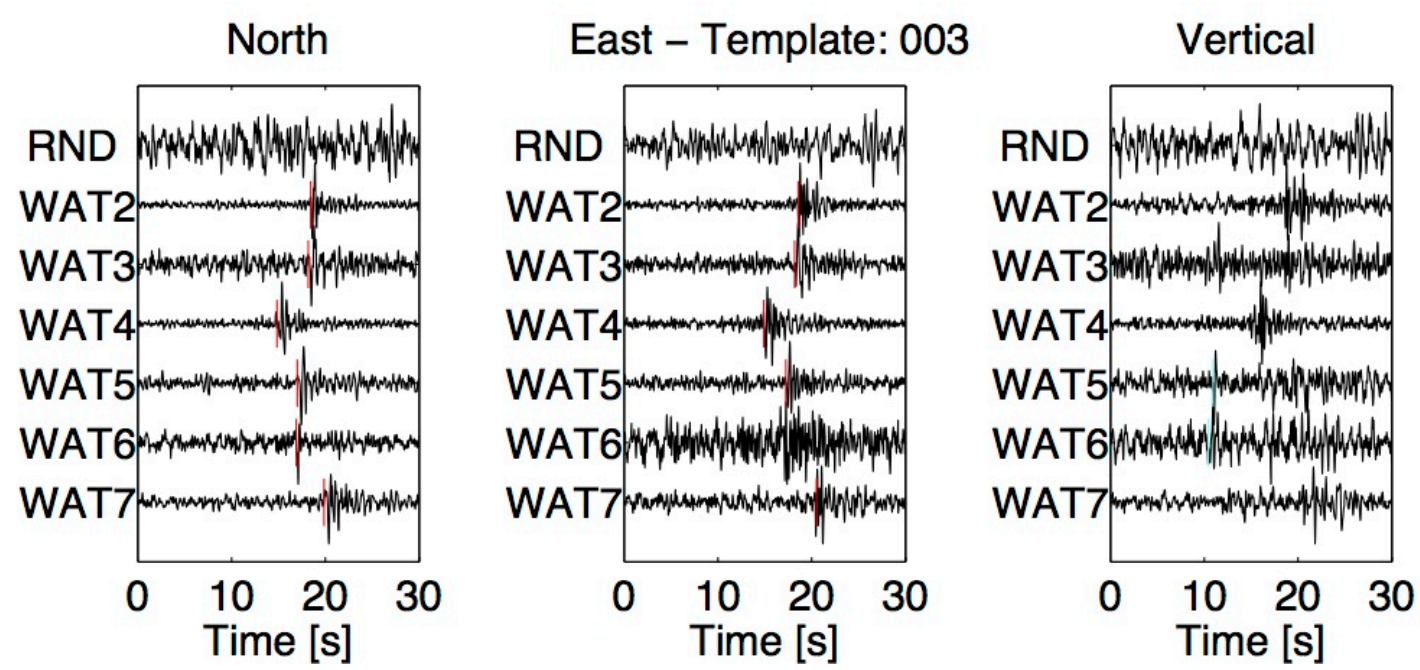

Figure 2.4. Particle-velocity waveforms for LFE template 3. See Figure 2.2 for details.
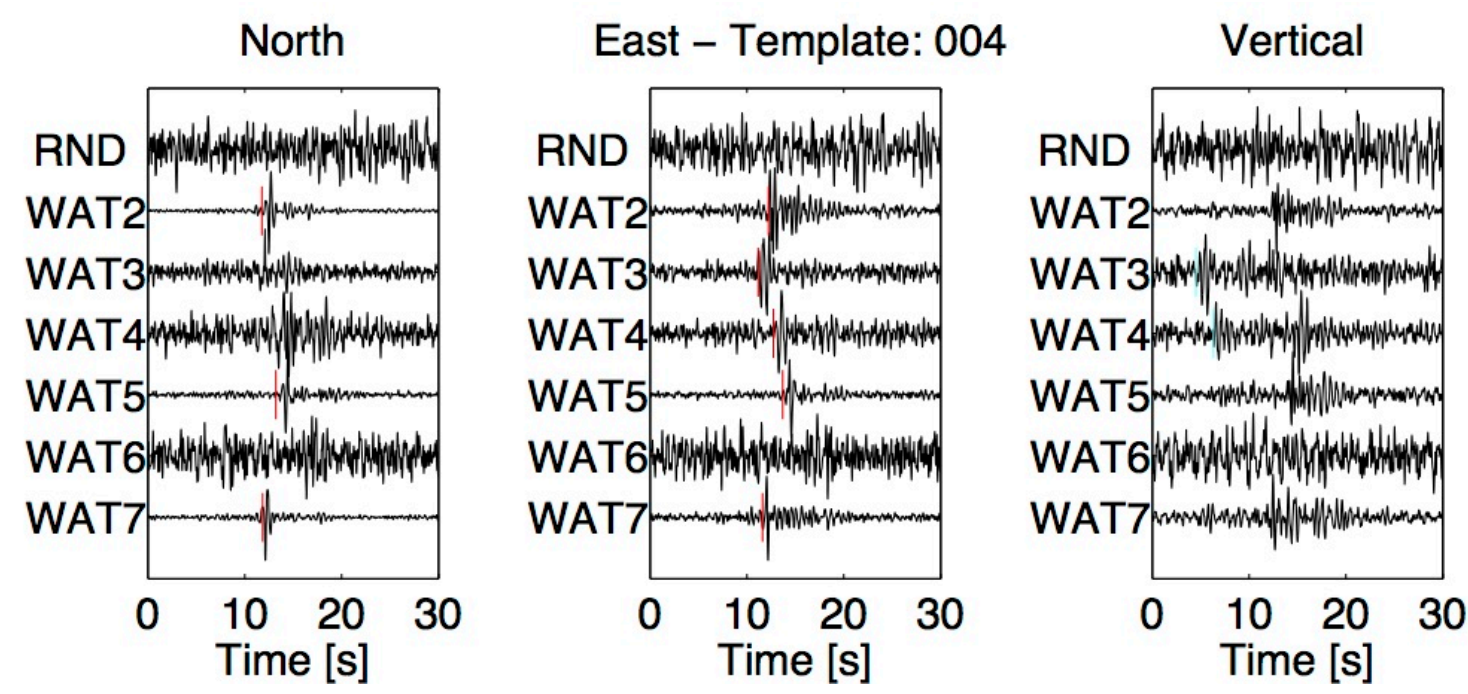

Figure 2.5. Particle-velocity waveforms for LFE template 4. See Figure 2.2 for details. 

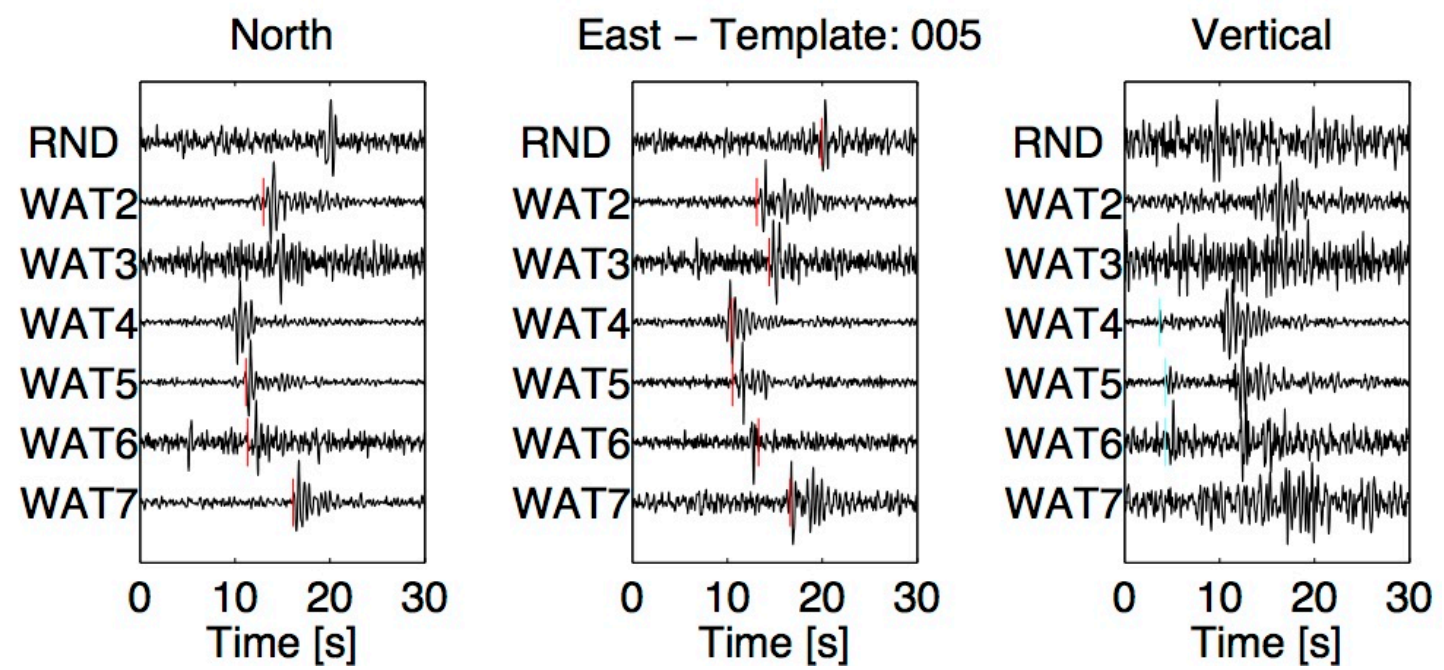

Figure 2.6. Particle-velocity waveforms for LFE template 5. See Figure 2.2 for details.
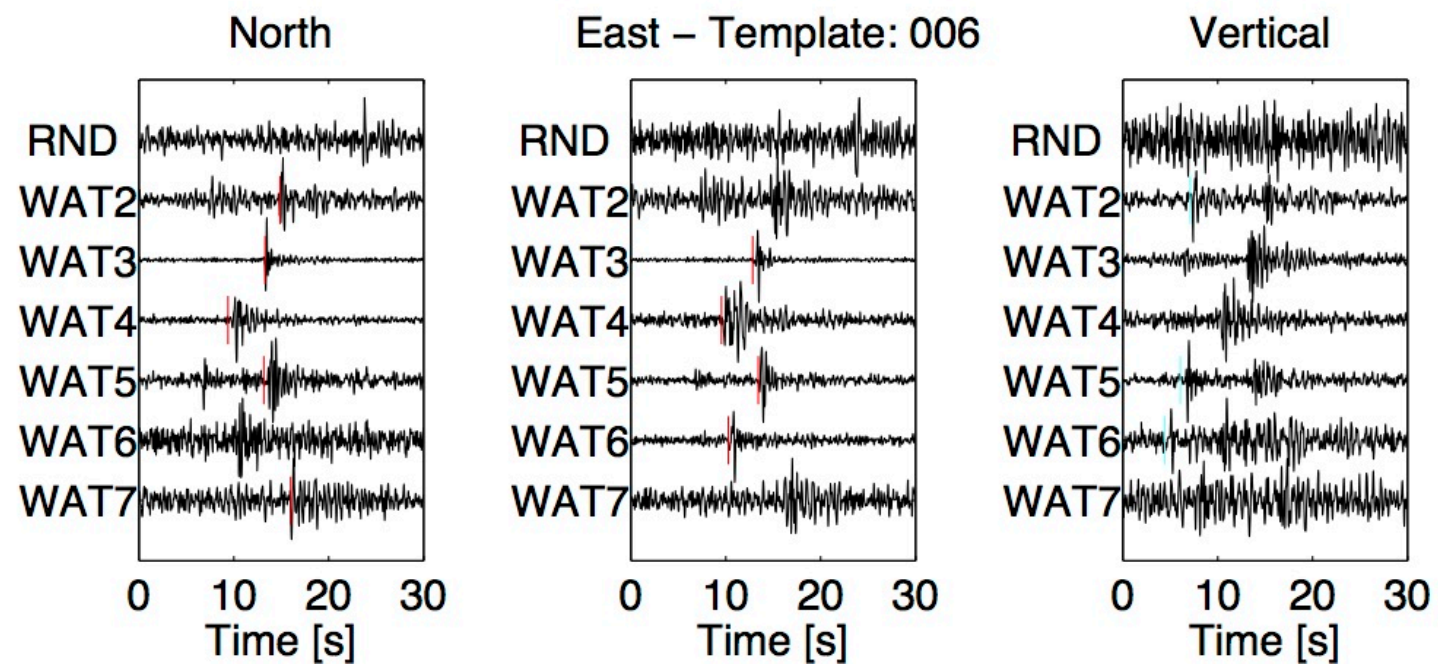

Figure 2.7. Particle-velocity waveforms for LFE template 6. See Figure 2.2 for details.

\subsection{LFE Template Hypocentral Location}

Signal-to-noise ratios of the LFE template waveforms were sufficient to pick arrival times of at least $2 \mathrm{P}$-wave and $8 \mathrm{~S}$-waves for each template enabling accurate determination of hypocentral depths which is not possible for raw tremor waveforms. We employed 
USGS Hypoinverse (Klein, 2002) software and the USGS Southern Alaska velocity model (Fogelman et al, 1993, see Table 2) used by Wech (2015) in his tremor study and the Alaska Earthquake Center for regular earthquakes in this region. LFE template hypocenters are listed in Table 3 with nominal errors in horizontal and vertical coordinates of $0.15 \mathrm{~km}$ and $1.17 \mathrm{~km}$, respectively.

Table 2.1. Locations of stations employed in this study.

\begin{tabular}{|c|c|c|}
\hline Station & Latitude $\left({ }^{\circ} \mathbf{N}\right)$ & Longitude $\left({ }^{\circ} \mathbf{W}\right)$ \\
\hline GHO & 61.7716 & -148.9238 \\
\hline HARP & 62.3986 & -145.1567 \\
\hline PAX & 62.9699 & -145.4699 \\
\hline RND & 63.4056 & -148.8602 \\
\hline SAW & 61.8070 & -148.3318 \\
\hline SCM & 61.8329 & -147.3296 \\
\hline WAT1 & 62.8295 & -148.5509 \\
\hline WAT2 & 62.9628 & -148.5855 \\
\hline WAT3 & 62.6812 & -148.5377 \\
\hline WAT4 & 62.8349 & -147.9421 \\
\hline WAT5 & 63.0624 & -148.2286 \\
\hline WAT6 & 62.5808 & -147.7400 \\
\hline WAT7 & 62.8331 & -148.8476 \\
\hline & & \\
\hline
\end{tabular}


Table 2.2. P wave Velocity model of Southern Alaska

\begin{tabular}{|c|c|}
\hline P-velocity $(\mathbf{k m} / \mathbf{s})$ & Depth $(\mathbf{k m})$ \\
\hline 5.3 & 0.0 \\
\hline 5.6 & 4.0 \\
\hline 6.2 & 10.0 \\
\hline 6.9 & 20.0 \\
\hline 7.4 & 25.0 \\
\hline 7.7 & 33.0 \\
\hline 7.9 & 47.0 \\
\hline 8.1 & 65.0 \\
\hline 8.3 & \\
\hline
\end{tabular}

Southern Alaska P-velocity model employed in the hypocentral location of LFE templates from central Alaska. S-velocities were computed from the P-velocity model assuming $\mathrm{Vp} / \mathrm{Vs}=\operatorname{sqrt}(3)$. 
Table 2.3. LFE template hypocenters.

\begin{tabular}{|c|c|c|c|}
\hline Template \# & Latitude $\left({ }^{\circ} \mathbf{N}\right)$ & Longitude $\left({ }^{\circ} \mathbf{W}\right)$ & Depth(km) \\
\hline 1 & 62.433 & 147.883 & 40.3 \\
\hline 2 & 62.550 & 147.500 & 42.2 \\
\hline 3 & 62.833 & 147.833 & 50.2 \\
\hline 4 & 62.733 & 148.617 & 57.6 \\
\hline 5 & 62.933 & 147.550 & 50.2 \\
\hline 6 & 62.733 & 147.750 & 45.5 \\
\hline
\end{tabular}

LFE epicenters cluster in the region of highest station density. Figure 3.1 displays LFE hypocenters at depths between 40 and $58 \mathrm{~km}$ on profile A-A' (see Figure 2.1 for location of profiles) along with regular earthquakes and the E115 plate model (e.g., Jadamec and Billen, 2010). A- $\mathrm{A}^{\prime}$ is oriented parallel to plate motion direction and orthogonal to slab depth contours in central Alaska. At near-epicentral distances, particle-velocity S waves are impulsive and display negative and positive polarity leading lobes on north and east components, respectively, whereas $\mathrm{P}$ waves are weak for this geometry, suggesting a nearly vertical nodal plane. Moreover, the character of LFE S waveforms is similar to those in Cascadia, displaying the dipolar pulse anticipated for point sources (Figure 2.8). 

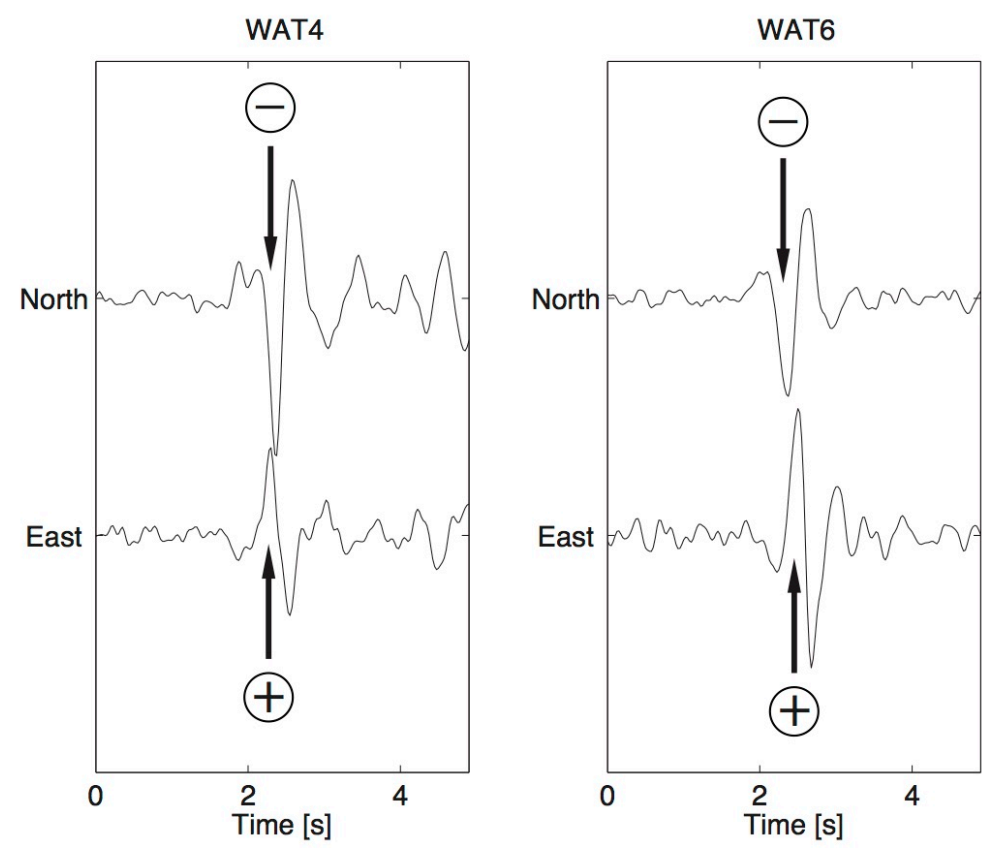

Figure 2.8. Particle velocity waveforms of $S$-waves on horizontal components at stations WAT4 and WAT6 for Template 1. Waveforms display simple dipolar signatures expected on particle velocity waveforms from a spatially confined source. Leading pulses on north and east components are negative and positive polarity, respectively, indicating south eastward motion of the overriding plate. 


\section{Discussion}

\subsection{LFEs Observations}

Slab model E115 is slightly below the locus of intraslab seismicity along $\mathrm{A}-\mathrm{A}^{\prime}$ at depths greater than $40 \mathrm{~km}$. Receiver function modeling suggests that most seismicity is within the thickened Yakutat crust and crosscuts it at an angle steeper by $\sim 2^{\circ}$, consistent with dehydration of hydrous minerals (Rondenay et al., 2008; Abers et al., 2013). The plate boundary must therefore be near the upper envelope of seismicity. LFE depths afford a direct estimate for the position of the plate boundary. S wave polarities on LFE template waveforms are consistent with north-northwest subduction and with the general consensus that LFEs represent shear slip on the plate boundary (e.g., Ide et al., 2007). As evident on profile A-A' (Fig. 3.1A), the six LFE families approximately align with the upper envelope of intraslab seismicity. Moreover, the strongest concentration of intraslab seismicity commences just downdip of the deepest LFE template and tremor, and coincides with an increase in slab dip. 

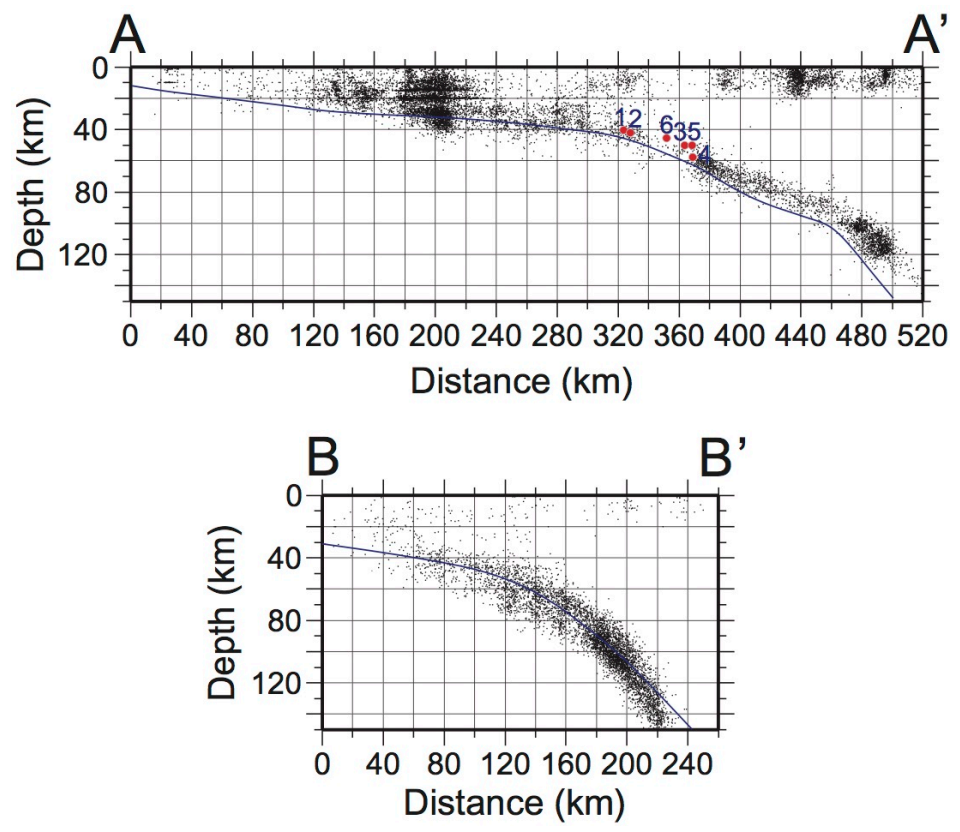

Figure 3.1. Depth distribution of intraslab seismicity and low-frequency earthquakes (LFEs) along profiles $A-A^{\prime}$ and $B-B^{\prime}$ in Figure 2.1. Black dots and red circles indicate intraslab seismicity and LFEs (labelled in blue) within $\sim 35 \mathrm{~km}$ of $A-A^{\prime}$, respectively. The E115 slab interface is shown in blue.

\subsection{LFEs and LVZs in Warm Subduction Zones}

To gain insight into the implications of these observations, we summarize relevant findings from Cascadia and Nankai, where tremor and LFEs similar to those observed in Alaska have been documented (Ide, 2012). These warm subduction zones are marked by (1) young ocean crust, (2) low volcanic output, (3) shallow slab dips, (4) episodic tremor and slow slip, and (5) distinct geometric associations between seismicity, tremor, and LVZs with elevated Vp/Vs (Vp_-P wave velocity; Vs-S wave velocity) (Shelly et al., 2006; Audet et al., 2009; Kato et al., 2010). High Vp/Vs ratios manifest near-lithostatic pore pressures conducive to slow slip phenomena. Along the Cascadia margin, the LVZ displays a two-layer structure with upper layer displaying lower velocity and higher $\mathrm{Vp} / \mathrm{Vs}$ 
than the lower layer. The composite LVZ is variously interpreted as metasediments above oceanic crust (Abers et al., 2009), or the metamorphosed equivalent of hydrated pillow basalts and sheeted dikes (layer 2) plus or minus sediments above a drier gabbroic lower crust (layer 3) (Bostock, 2013). LFEs in Cascadia and Nankai are located near the top of the LVZ, 5-10 km above intraslab seismicity (Shelly et al., 2006; Bostock et al., 2012). In Cascadia tremors are spatially anti-correlated with earthquakes, and bracketed updip and downdip by increased intraslab seismicity (e.g., Kao et al., 2009). The downdip seismicity increase often coincides with a reduction in LVZ contrast and increase in slab dip. Intraslab events occur within the uppermost mantle through antigorite dehydration and in the lowermost crust as a result of eclogitization (e.g., Rondenay et al., 2008; Abers et al., 2013; Bostock, 2013). Warm slab temperatures lead to early onset of dehydration, and maintenance of high pore pressure implies a seal along the plate boundary (Audet et al., 2009; Kato et al., 2010). This seal is thought to be breached at depths of $>40 \mathrm{~km}$ in Cascadia, due to the large solid-solid volume decrease accompanying eclogitization (Audet et al., 2009), as signaled by a top-down waning in LVZ contrast with depth (Rondenay et al., 2008). Expulsion of hydrous fluid into the shallow mantle wedge limits that available to fuel arc volcanism, reducing magmatic output along the Cascade arc (Kirby et al., 1996). Loss of fluids at shallow depth is also evident in Nankai where young arc volcanism is all but absent.

Tremors and seismicity in Alaska share many associations typical of warm subduction zones despite classification of Alaska in the mid-range of slab thermal 
structures globally (Kirby et al., 1996) and a ca. 50 Ma age of Yakutat crust at the trench. Specifically, we note that LFE locations are aligned with the top of an LVZ and the upper envelope of intraslab seismicity, and immediately updip of increased slab dip and seismicity levels signaling onset of eclogitization (Rondenay et al., 2008; Abers et al., 2013). In addition, tremor distribution is mirrored downdip by a lack of arc volcanism defining the DVG. This correlation prompts speculation about whether the DVG is due to fluid expulsion at depths too shallow to permit partial melt generation, the mechanism usually cited for weak volcanism in warm subduction zones. A model supporting this hypothesis and consistent with previous geophysical results is depicted in Figure 3.2A and detailed in the following.

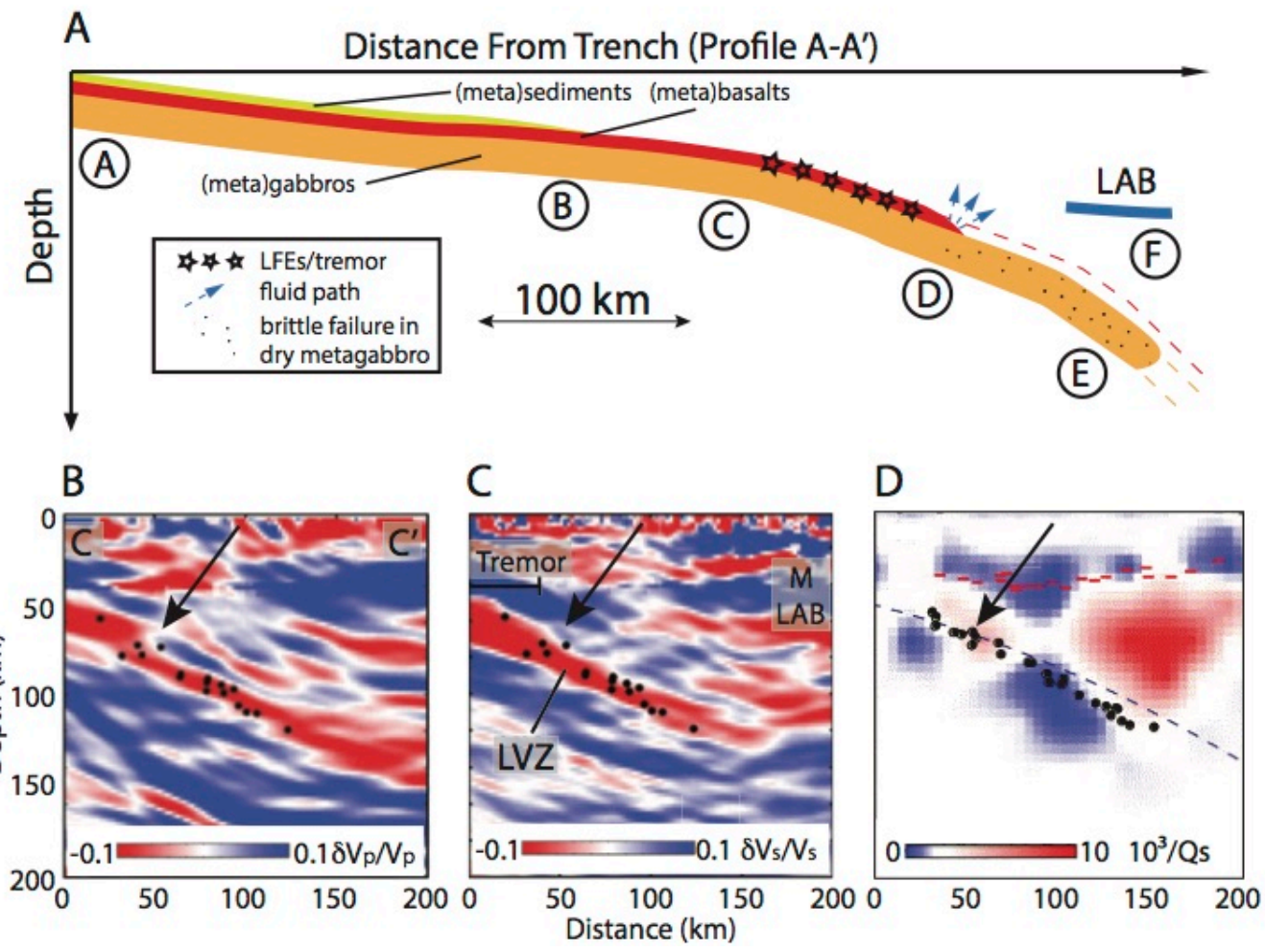

Figure 3.2. Yakutat subduction model. A: Illustration of stages (circled A-F) in proposed model along profile A-A'. Black circles mark intraslab events. 
LAB - lithosphere-asthenosphere boundary; LFE - low-frequency earthquakes. See text for details. B: Images of $P$ wave velocity perturbation across profile $C-C^{\prime}$ in figure 2.1. $C$ : $S$ wave velocity perturbation from Rondenay et al. (2010) across profile C-C'. Locations of Moho (M) and LAB are labeled. LVZ-low-velocity zone. D: Inverse Qs structure from

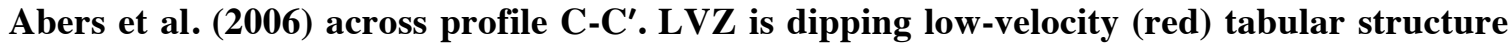
in B and C. Dashed line is top of slab in D. Arrows point to common location along slab marking eclogitization of Yakutat upper crust and fluid release into wedge mantle. $Q \mathrm{~s}-\mathrm{S}$ wave quality factor.

\subsection{Fluid Distribution and Seismogenesis}

We propose that the Yakutat slab water budget is confined to the top few kilometers of crystalline crust. Offshore seismic refraction profiles reveal Yakutat crust between 24 and $27 \mathrm{~km}$ in thickness overlain by $4.5-7.5 \mathrm{~km}$ of sediments, and a velocity structure consistent with an oceanic plateau interpretation (Christeson et al., 2010; stage A in Fig. 3.2A). Most sediments are plausibly shed through accretion and underplating (von Huene et al., 2012; stage B) over an $\sim 400 \mathrm{~km}$ shallow-dip transit from trench to the tremor zone, where the LVZ thickness is estimated as $\sim 20 \mathrm{~km}$. Shallow slab dip is sustained by a buoyant, thickened Yakutat crust (Abers, 2008). Some sediment may persist into the tremor zone, but the major fluid contribution is in the upper crust of the subducting plate, as argued in, e.g., Hansen et al., (2011) and Bostock (2013) for Cascadia. Offshore, Yakutat upper crust may be twice as thick as normal upper crust (i.e., layer 2; Christeson et al., 2010), but constitutes a disproportionately small fraction of the total $\sim 25-\mathrm{km}$-thick crustal edifice. The remaining crystalline basement of the Yakutat crustal section is assumed to be mafic, consistent with an oceanic plateau interpretation, and anhydrous (Hacker, 1996). In particular, it is inferred to contain still less fluid than normal lower crust (i.e., layer 3; e.g., 
Cascadia; Bostock, 2013) due to shielding against penetrative hydrothermal circulation in the offshore by thick sedimentary and upper crustal sequences. A corollary is that underlying Yakutat mantle is still drier than normal slab mantle.

We suggest that increased plate coupling during shallow subduction of the Yakutat terrane to the tremor zone (Jadamec et al., 2013) leads to hydromechanical conditions (increased shear heating, grain-size reduction, seal development, and breach by eclogitization) on top of the slab akin to those in warm slab environments such as Cascadia, promoting slow-slip phenomena through pervasive fluid at high pore pressure (stage C; Bostock, 2013). Immediately downdip of the tremor zone, eclogitization of metabasaltic Yakutat upper crust is initiated and accelerated by the fluid presence (Hacker, 1996), and possibly stress transfer via slow slip accompanying tremor (stage D). The large volume change accompanying eclogitization compromises the plate boundary seal, expelling fluid into the mantle wedge over a narrow depth range starting near $60 \mathrm{~km}$. Independent $\mathrm{P}$ and $\mathrm{S}$ mode scattered wave images suggest that the LVZ thins by $\sim 5 \mathrm{~km}$ from the top down near $60 \mathrm{~km}$ depth, signaling the velocity increase due to eclogitization of the upper crust (Rondenay et al., 2010; Figs. 3.2B and 3.2C). Substantial fluid release over a limited depth interval is supported by a localized low Qs (S wave quality factor) anomaly in the tomography model of Abers et al. (2006; Fig. 3.2D). The shallow depths $(\sim 60-80 \mathrm{~km})$ at which the slab fluid budget is expended preclude it from catalyzing partial melting, with a consequent absence of arc volcanism along the DVG. 
At depths below where eclogitization of upper crust initiates, seismic expressions of Yakutat and Cascadia LVZs differ significantly (e.g., Rondenay et al., 2010). Eclogitization proceeds from the top down in Cascadia, as evidenced by a diminishing upper boundary contrast, culminating near $\sim 100 \mathrm{~km}$ depth with erasure of the lower boundary contrast at the oceanic Moho. In contrast, the thinned Yakutat LVZ, inferred here to be lower crustal metagabbros, retains comparable upper and lower contrasts to depths near $120 \mathrm{~km}$. Moreover, whereas intraslab seismicity in Cascadia occurs in both the deeper metagabbros and the shallow upper mantle, seismicity in the Yakutat terrane is confined to the LVZ (Abers et al., 2013). The absence of mantle earthquakes is unusual in a global context, because subduction zones of this age typically exhibit double seismic zones with a lower mantle plane attributed to embrittlement via antigorite dehydration (Brudzinski et al., 2007). In particular, younger (ca. $38 \mathrm{Ma}$ ) subducting Pacific lithosphere to the west below Cook Inlet has healthy volcanic output and displays a thicker Wadati-Benioff zone (see Fig. 3.1B) that reveals a double seismic zone at high resolution (Ratchkovsky et al., 1997).

This peculiar seismicity distribution can be explained through a Yakutat lower crust and mantle that are significantly drier than those of normal oceanic lithosphere. Mantle seismicity is lacking due to the absence of antigorite. Eclogitization of metagabbros is kinetically hindered and proceeds more gradually than in overlying metabasalts due to prevailing anhydrous conditions (Hacker, 1996). Preservation of both upper and lower LVZ contrasts (versus a top-down erasure as in Cascadia) and the observation of Abers et al. $(2013,2006)$ that seismicity crosscuts the LVZ at a shallow angle consistent with 
equilibrium thermodynamics of eclogitization can be reconciled if catalyzing fluids are restricted to a low density of volumetrically minor faults, leaving large tracts of metastable metagabbro intact to depths $>100 \mathrm{~km}$ (stage E). Alternatively, thermally induced shear instabilities that do not require a fluid presence may govern seismogenesis in the metagabbros (Deseta et al., 2014). We suggest that the increased concentration and dip of seismicity at depths of $100-120 \mathrm{~km}$ in Figure 3.1A are evidence for accelerated eclogitization in the Yakutat lower crust at pressures far above equilibrium, leading to LVZ extinction with negligible fluid release.

This model is an alternative to one where the DVG is modeled through Yakutat slab advance, mantle wedge cooling, and ponding of otherwise normal arc magmas below an impermeable mantle boundary near $60 \mathrm{~km}$ depth (Rondenay et al., 2010). That model also addresses the presence of a prominent negative velocity contrast (lithosphere-asthenosphere boundary, LAB in Fig. 3.2C) beginning 50-60 km landward of the tremor zone. In the present context, we suggest that this feature represents the LAB. The LAB is commonly imaged in tectonically active regions such as the western U.S. at comparable depths and is thought to represent a steep gradient in mantle hydration state from refractory lithosphere to wetter asthenosphere (Fischer et al., 2010). Its prominent expression in central Alaska may result through punctuated fluid release from the Yakutat slab immediately below the tremor zone (stage F). 


\section{Conclusions}

Common associations between LFEs, seismicity, and LVZ structure in Alaska and warm subduction zones, together with the observation that tremor distribution is paralleled downdip by the DVG, motivate a new model for this enigmatic feature. We propose that the fluid budget of the subducting Yakutat terrane is confined to its upper crust, and that tremor generation is enabled by hydromechanical conditions on top of the slab developed through shallow subduction. As a consequence, fluids are expelled at depths too shallow to allow generation of significant partial melts and arc volcanism. Moreover, the lack of double seismic zone and restriction of intraslab seismicity to a metagabbroic LVZ with persistent velocity contrast are simply explained through anhydrous conditions prevailing in the Yakutat metagabbroic lower crust and upper mantle. 


\section{References}

Abers, G.A., 2008, Orogenesis from subducting thick crust and evidence from Alaska, in Freymueller, J.G., et al., eds., Active tectonics and seismic potential of Alaska: American Geophysical Union Geophysical Monograph 179, p. 337-349, doi:10.1029/179GM19.

Abers, G.A., van Keken, P., Kneller, E.A., Ferris, A., and Stachnik, J.C., 2006, The thermal structure of subduction zones constrained by seismic imaging: Implications for slab dehydration and wedge flow: Earth and Planetary Science Letters, v. 241, p. 387-397, doi:10.1016/j.eps1.2005.11.055.

Abers, G.A., MacKenzie, L.S., Rondenay, S., Zhang, Z., Wech, A.G., and Creager, K.C., 2009, Imaging the source region of Cascadia tremor and intermediatedepth earthquakes: Geology, v. 37, p. 1119-1122, doi:10.1130/G30143A.1.

Abers, G.A., van Keken, P., Kita, S., and Hacker, B., 2013, Thermal-petrological controls on the location of earthquakes within subducting plates: Earth and Planetary Science Letters, v. 369-370, p. 178-187, doi:10.1016/j.eps1.2013.03.022.

Audet, P., Bostock, M., Christensen, N., and Peacock, S., 2009, Seismic evidence for overpressured subducted oceanic crust and megathrust fault sealing: Nature, v. 457, p. 76-78, doi:10.1038/nature07650.

Bostock, M., 2013, The Moho in subduction zones: Tectonophysics, v. 609, p. 547- 557, doi:10.1016/j.tecto.2012.07.007.

Bostock, M., Royer, A., Hearn, E., and Peacock, S., 2012, Low frequency earthquakes below southern Vancouver Island: Geochemistry, Geophysics, Geosystems, v. 13, Q11007, doi:10.1029/2012GC004391.

Brudzinski, M.R., Thurber, C.H., Hacker, B.R., and Engdahl, E.R., 2007, Global prevalence of double Benioff zones: Science, v. 316, p. 1472-1474, doi: 10.1126/science. 1139204 . 
Christeson, G.L., Gulick, S.P.S., van Avendonk, H.J.A., Worthington, L.L., Reece, R.S., and Pavlis, T.L., 2010, The Yakutat terrane: Dramatic change in crustal thickness across the Transition fault: Geology, v. 38, p. 895-898, doi:10.1130/G31170.1.

Deseta, N., Ashwal, L., and Andersen, T., 2014, Initiating intermediate-depth earthquakes: Insights from a HP-LT ophiolite from Corsica: Lithos, v. 206, p. 127-146, doi:10.1016/j.lithos.2014.07.022.

Fischer, K., Ford, H.A., Abt, D.L., and Rychert, C.A., 2010, The lithosphere asthenosphere boundary: Annual Review of Earth and Planetary Sciences, v. 38, p. 551-575, doi:10.1146/annurev-earth-040809-152438.

Hacker, B.R., 1996, Eclogite formation and the rheology, buoyancy, seismicity, and H2 O content of oceanic crust, in Bebout, G.E, et al., eds., Subduction top to bottom: American Geophysical Union Geophysical Monograph 96, p. 337-346, doi:10.1029/GM096p0337.

Hansen, R.T.J., Bostock, M.G., and Christensen, N.I., 2012, Nature of the low velocity zone in Cascadia from receiver function waveform inversion: Earth and Planetary Sciences, v. 337-338, p. 25-38, doi:10.1016/j.eps1.2012.05.031.

Ide, S., 2012, Variety and spatial heterogeneity of tectonic tremor worldwide: Journal of Geophysical Research, v. 117, B03302, doi:10.1029/2011JB008840.

Ide, S., Shelly, D.R., and Beroza, G.C., 2007, Mechanism of deep low frequency earthquakes: Further evidence that deep non-volcanic tremor is generated by shear slip on the plate interface: Geophysical Research Letters, v. 34, L03308, doi:10.1029/2006GL028890.

Jadamec, M.A., and Billen, M.I., 2010, Reconciling surface plate motions with rapid three-dimensional mantle flow around a slab edge: Nature, v. 465, p. 338-342, doi:10.1038/nature09053.

Jadamec, M.A., Billen, M.I., and Roeske, S.M., 2013, Three-dimensional numerical models of flat slab subduction and the Denali fault driving deformation in 
south-central Alaska: Earth and Planetary Science Letters, v. 376, p. 29-42, doi:10.1016/j.eps1.2013.06.009.

Kao, H., Shan, S.-J., Dragert, H., and Rogers, G.C., 2009, Northern Cascadia episodic tremor and slip: A decade of tremor observations from 1997 to 2007: Journal of Geophysical Research, v. 114, B00A12, doi:10.1029/2008JB006046.

Kato, A., et al., 2010, Variations of fluid pressure within the subducting oceanic crust and slow earthquakes: Geophysical Research Letters, v. 37, L14310, doi:10.1029/2010GL043723.

Kim, Y., Abers, G.A., Li, J., Christensen, D., and Calkins, J., 2014, Alaska megathrust 2: Imaging the megathrust zone and Yakutat/Pacific plate interface in the Alaska subduction zone: Journal of Geophysical Research, v. 119, p. 1924- 1941, doi:10.1002/2013JB010581.

Kirby, S., Engdahl, R., and Denlinger, R., 1996, Intermediate-depth intraslab earthquakes and arc volcanism as physical expressions of crustal and uppermost mantle metamorphism in subducting slabs, in Bebout, G. E., et al., eds., Subduction top to bottom: American Geophysical Union Geophysical Monograph 96, p. 195-214, doi:10.1029/GM096p0195.

McGeary, S., Nur, A. and Ben-Avraham, Z., 1985. Spatial gaps in arc volcanism: the effect of collision or subduction of oceanic plates. In: N.L. Carter and S. Uyeda (Editors), Collision Tectonics: Deformation of Continental Lithosphere. Tectonophysics, 119: 195-221.

Peterson, C.L., and Christensen, D.H., 2009, Possible relationship between nonvolcanic tremor and the 1998-2001 slow slip event, south central Alaska: Journal of Geophysical Research, v. 114, B06302, doi:10.1029/2008JB006096.

Plafker, G., Moore, J., and Winkler, G., 1994, Geology of the southern Alaska margin, in George, B.H., and Plafker, G., eds., The geology of Alaska: Boulder, Colorado, Geological Society of America, Geology of North America, v. G-1, p. 389-448, doi:10.1130/DNAG-GNA-G1.389. 
Ratchkovsky, N.A., Pujol, J., and Biswas, N.N., 1997, Stress pattern in the double seismic zone beneath Cook Inlet, south-central Alaska: Tectonophysics, v. 281, p. 163-171, doi:10.1016/S0040-1951(97)00042-5.

Rondenay, S., Abers, G., and van Keken, P., 2008, Seismic imaging of subduction zone metamorphism: Geology, v. 36, p. 275-278, doi:10.1130/G24112A.1.

Rondenay, S., Montési, L.G.J., and Abers, G.A., 2010, New geophysical insight into the origin of the Denali volcanic gap: Geophysical Journal International, v. 182, p. 613630, doi:10.1111/j.1365-246X.2010.04659.x.

Shelly, D.R., Beroza, G.C., Ide, S., and Nakamura, S., 2006, Low-frequency earthquakes in Shikoku, Japan, and their relationship to episodic tremor and slip: Nature, v. 442, p. 188-191, doi:10.1038/nature04931.

Shelly, D., Beroza, G.C., and Ide, S., 2007, Non-volcanic tremor and low-frequency earthquake swarms: Nature, v. 446, p. 305-307, doi:10.1038/nature05666.

von Huene, R., Miller, J., and Wienrebe, W., 2012, Subducting plate geology in three great earthquake ruptures of the western Alaska margin, Kodiak to Unimak: Geosphere, v. 8, p. 628-644, doi:10.1130/GES00715.1.

Wech, A., 2016, Extending Alaska's plate boundary: Tectonic tremor generated by Yakutat subduction: Geology, v. 44, p. 587-590, 